\title{
Symbiont abundance in thyasirids (Bivalvia) is related to particulate food and sulphide availability
}

\author{
Suzanne C. Dufour ${ }^{1,2, *}$, Horst Felbeck $^{1}$ \\ ${ }^{1}$ Marine Biology Research Division, Scripps Institution of Oceanography, 9500 Gilman Drive, \\ La Jolla, California 92093-0202, USA
}

\begin{abstract}
${ }^{2}$ Present address: Institut des Sciences de la Mer de Rimouski, Université du Québec à Rimouski, 310 allée des Ursulines,
\end{abstract} CP 3300, Rimouski, Québec G5L 3A1, Canada

\begin{abstract}
Many bivalve species with chemoautotrophic symbionts have mixotrophic diets and some of their nutritional requirements are met by particulate feeding. The symbionts require reduced compounds (such as sulphide) for their autotrophic production. As the concentration of both particulate food and sulphide can vary in their habitat, it has been suggested that symbiont numbers may vary in response. To address whether symbiont abundance can be influenced by the external medium, we compared symbiont abundance (1) in specimens kept with or without particulate food, and (2) in specimens kept in sediments with low or high dissolved sulphide content. The relative surface area occupied by symbionts on semi-thin gill sections was determined for Thyasira flexuosa (and, in the sulfide experiment, for Parathyasira equalis and T. sarsi) kept for up to 3 wk in experimental microcosms, where the quantity of particulate food or dissolved sulphide was manipulated. Symbiont abundance declined with time; the decline was greater in particle-starved thyasirids and in specimens kept in low sulphide. In the latter conditions, T. flexuosa may have also had a greater symbiont digestion rate. The observed patterns may be due to a combination of increased symbiont uptake by the bivalve host, and reduced symbiont vigour under the imposed conditions. The flexible feeding mode of chemosymbiotic thyasirids may help them to survive in fluctuating environments.
\end{abstract}

KEY WORDS: Symbiosis · Chemoautotrophic symbionts $\cdot$ Thyasiridae $\cdot$ Bivalves $\cdot$ Feeding $\cdot$ Sulphide

\section{INTRODUCTION}

Many bivalves are known to live in association with chemoautotrophic bacteria, from which they derive some nutritional benefit (Le Pennec et al. 1995a, Distel 1998, Le Pennec \& Beninger 2000). The symbiotic bacteria in these associations depend on energy-rich reduced chemical compounds, such as hydrogen sulphide or methane, to drive carbon fixation. Either the products of bacterial autotrophic production, or the bacteria themselves, can be assimilated by the host bivalve (Herry et al. 1989, Barry et al. 2002).

Many chemosymbiotic bivalves do not obtain all their nutrients from symbionts: essential fatty acids and vitamins may have to be obtained by pathways other than symbiosis (Fullarton et al. 1995). For most bivalve species, particulate feeding is the main alter- native; dissolved organic matter may also be taken up through the epithelia (Péquignat 1973, Wright 1982). Evidence for feeding includes the presence of particulate matter and digestive enzymes in the gut of chemosymbiotic bivalves (Le Pennec et al. 1990), and the demonstration of radiolabelled carbon uptake through digestion (Duplessis et al. 2004).

The relative importance of symbiont-derived and particulate-derived nutrition can change seasonally or yearly in some bivalve species, as evidenced by changes in carbon isotope $\left(\delta^{13} \mathrm{C}\right)$ ratios in host tissues, reflecting the proportion of carbon assimilated from chemosynthetic or photosynthetic sources (Dando \& Spiro 1993, Le Pennec et al. 1995b). There is some evidence that changes in the relative importance of different food sources may be correlated with particulate food abundance: variability in nitrogen isotope ratios 
in chemosymbiotic mussel tissues suggests that the amount of nitrogen assimilated through feeding and dissolved inorganic nitrogen (DIN) uptake varies along with spatial and temporal patchiness in DIN and plankton (Pile \& Young 1999). Also, seasonal changes in the abundance of suspended particles were correlated with the appearance of secretory and digestive cells in the digestive gland of Thyasira flexuosa, indicating a greater reliance on particulate food in spring and on symbionts during winter months (Donval et al. 1988). Taken together, these results imply that the relative symbiont contribution to host bivalve nutrition is not constant, and that the association may be plastic in the face of environmental change.

Chemosymbiotic bivalves living where sulphide or methane is produced by the microbial degradation of organic matter under anoxia may have to deal with pronounced variations in the abundance of this resource (especially if there is a seasonal component to organic enrichment) and/or to the current regime regulating the flow of oxygenated water in the given habitat. Chemosymbiotic thyasirids may inhabit coastal and shelf sediments having temporally and spatially variable organic matter and reduced sulphur content (Dando \& Southward 1986, López-Jamar \& Parra 1997). In some thyasirids, tissue $\delta^{13} \mathrm{C}$ ratios were found to vary from one year to the next; it was concluded that their dependence upon symbionts varied as well, according to the quantity of available dissolved sulphide (Dando \& Spiro 1993). The species Thyasira sarsi and Lucinoma borealis can also utilize insoluble sulphur species (such as iron-bound sulphides; Dando et al. 1994, 2004). The concentration of insoluble sulphur compounds in marine sediments depends on microbial sulphate reduction rates and on the density of the exploiting bivalves (Dando et al. 2004); as for dissolved sulphide, their concentration can vary seasonally and yearly (Dando et al. 1994).

Although environmental parameters (i.e the availability of particulates or reduced suphur) seem to affect the relative contribution of symbionts to their host's nutrition, it remains unclear whether symbiont abundance could be affected by these parameters. Here, microcosm experiments were used to determine whether symbiont abundance in specimens of Thyasira flexuosa, T. sarsi and Parathyasira equalis is affected by: (1) the removal of suspended food (tested in T. flexuosa only), and (2) the dissolved sulphide content within the sediment. In those thyasirids, symbionts occur extracellularly, among bacteriocyte microvilli (Southward 1986, Dufour 2005): the host cells can engulf and digest symbionts, as evidenced by remains such as dark granules (Southward 1986). The percent space occupied by symbionts on semi-thin sections of bacteriocytes is used to estimate symbiont abundance.

\section{MATERIALS AND METHODS}

Specimen collection. In January 2002, specimens of Thyasira flexuosa (size range: 2 to $6 \mathrm{~mm}$ ) were collected from 13 to $16 \mathrm{~m}$ depth in the harbour of La Coruña, Spain. Sediment and bivalves were obtained from the sites DB $\left(43^{\circ} 21.88^{\prime} \mathrm{N}, 8^{\circ} 23.22^{\prime} \mathrm{W}, \mathrm{n}=100\right)$ and $5\left(43^{\circ} 21.45^{\prime} \mathrm{N}, 8^{\circ} 22.40^{\prime} \mathrm{W}, \mathrm{n}=60\right)$ given by LópezJamar et al. (1995) and López-Jamar \& Mejuto (1985), respectively, using a box corer. Thyasirids were retrieved on a sieve with $0.5 \mathrm{~mm}$ mesh size.

In October 2002, specimens of Thyasira flexuosa, T. sarsi and Parathyasira equalis were collected near Bergen, Norway, from 2 sites: the Raunefjord $\left(60^{\circ} 16.24^{\prime} \mathrm{N}, 5^{\circ} 08.63^{\prime} \mathrm{E}, 220\right.$ to $253 \mathrm{~m}$ depth) and Dolviken $\left(60^{\circ} 19.19^{\prime} \mathrm{N}, 5^{\circ} 15.34^{\prime} \mathrm{E}, 50\right.$ to $54 \mathrm{~m}$ depth). Using a Van Veen grab, sediment from both sites was collected and passed through a sieve with a $1 \mathrm{~mm}$ mesh size. Specimens of $P$. equalis $(\mathrm{n}=91)$ were obtained from the first site, whereas specimens of $T$. flexuosa $(\mathrm{n}=66)$ and $T$. sarsi $(\mathrm{n}=58)$ were collected from the second site.

Laboratory maintenance. For the first experiment, 12 undisturbed sediment cores $(6$ to $7 \mathrm{~cm}$ long, diameter $=12 \mathrm{~cm}$ ) from La Coruña sites DB and 5 were placed into cylindrical plastic containers, to be used as microcosms for Thyasira flexuosa. After measuring organic matter content (percentage of dry weight lost after combustion at $500^{\circ} \mathrm{C}$ ) from a small sample (5 to $10 \mathrm{~g}$ ) at the surface of each core, it was determined that this value did not differ significantly between sites ( $t$-test, $\mathrm{p}=0.81$ ). Redox probe measurements indicated that sediments from both sites had reducing properties within a few centimeters from the surface (data not shown). Based on these observations, it was deemed that sediments from the 2 sites were not sufficiently different to have an effect on symbiont numbers, and so were not considered as different treatments. The sediment cores were placed into two 901 tanks, each of which was a closed system with circulating seawater at $12^{\circ} \mathrm{C}$, the same temperature as in their natural environment at the time of collection. One tank contained only $0.22 \mu \mathrm{m}$ filtered seawater, the other filtered seawater with a daily addition of live phytoplankton (Isochrysis aff. galbana, clone T. iso), at an average concentration of $5.5 \times 10^{4}$ cells $\mathrm{ml}^{-1}$. A third of the water from each tank was replaced every second day. The thyasirids ( $\mathrm{n}=6$ to 15 per core) were placed at the surface of each sediment core, and most had burrowed by the next day. Of the specimens that did not burrow, most were among the larger thyasirids collected; these specimens were not included in the analysis.

For the second experiment, sieved sediment from the Raunefjord was placed into 12 plexiglass aquaria 
(dimensions: $25 \mathrm{~cm} \times 25 \mathrm{~cm} \times 12 \mathrm{~mm}$; inner width: $6 \mathrm{~mm}$ ), which were held in $60 \mathrm{l}$ tanks filled with aerated seawater, maintained in the dark at $8{ }^{\circ} \mathrm{C}$, the same temperature as in their natural environment at collection time. Six aquaria contained sediment that was allowed to settle for $4 \mathrm{~d}$ prior to the addition of bivalves at the surface; in the 6 others, sediment was maintained for $4 \mathrm{wk}$ before adding bivalves. The longer settling time allowed the accumulation of sulphide through microbial activity; the experimental setup therefore included a 'low sulphide' and a 'high sulphide' treatment. In each aquarium from the low sulphide treatment, 4 Parathyasira equalis, 4 to 6 Thyasira sarsi, and 7 to 9 T. flexuosa were introduced. Specimens for the high sulphide treatment were collected 4 wk later; 5 to $7 P$. equalis, 1 to 2 T. sarsi, and 1 or $3 T$. flexuosa were placed in each aquarium. Water in the tanks was replaced daily, and phytoplankton from the Raunefjord (average concentration: $6.4 \times 10^{6}$ cells $\mathrm{ml}^{-1}$ ) was added daily to both tanks.

Sulphide determination. In the second experiment, interstitial water sulphide was measured in each microcosm after 1, 2 and 3 wk. Sediment samples were taken from the microcosms using a thin glass core, and sediment from consecutive $5 \mathrm{~cm}$ depth intervals was distributed into microtubes. The tubes were centrifuged to separate the pore water, which was pipetted into duplicate sulphide traps consisting of a mixture of zinc acetate and sodium hydroxide (Gilboa-Garber 1971). The manipulation was done quickly to minimize oxidation of sulphide in the pore water through contact with atmospheric oxygen. The sulphide content in each fraction was determined by colourimetry, as in Gilboa-Garber (1971).

Specimen fixation and gill sectioning. For the first experiment, 4 microcosms ( 2 each from the fed and unfed treatments) were taken from the tanks after 5, 11 and $18 \mathrm{~d}$. For the second experiment, 4 aquaria (2 each from the low and high sulphide treatments) were removed from the tanks after 1, 2 and $3 \mathrm{wk}$. On these days, the sediment from each microcosm was gently sieved to collect thyasirids.

All specimens were dissected and their gills were fixed in $3 \%$ glutaraldehyde in $0.1 \mathrm{M}$ sodium phosphate buffer with $0.35 \mathrm{M}$ sucrose for $1 \mathrm{~h}$. The fixed gills were then rinsed in $0.1 \mathrm{M}$ sodium phosphate buffer and postfixed in $1 \%$ osmium tetroxide (in the same buffer) for $1 \mathrm{~h}$. The gills were then dehydrated in an ascending ethanol gradient, and embedded in Spurr resin.

Transverse, semi-thin sections (1 to $2 \mu \mathrm{m}$ thick) of the gills were made, and stained for $30 \mathrm{~s}$ on a heating plate with $1 \%$ toluidine blue in $1 \%$ sodium borate $(\mathrm{pH} \approx 12)$, then rinsed in distilled water. Digital micrographs of each gill were taken at $400 \times$ magnification.
Ultra-thin (approximately $70 \mathrm{~nm}$ ) transverse sections of the gills of several samples (at least 3 freshly collected ind. of each species, and at least 2 individuals of each species after maintenance in the various treatments) were made to observe the symbionts within the bacteriocytes. The sections were stained with uranyl acetate and lead citrate prior to observation on a Philips 410A transmission electron microscope (TEM).

Determination of symbiont and dark granule abundance. From digital micrographs of the semi-thin sections at $400 \times$, the relative bacteriocyte area occupied by symbionts in each specimen was determined for the species Thyasira flexuosa (differential staining intensity by toluidine blue, which at the high $\mathrm{pH}$ levels optimal for resin sections stains several cell components including nuclear material and cell membranes, allowed a distinction of bacteria and host cytoplasm in T. flexuosa, but not in T. sarsi or P. equalis. The adequacy of other DNA stains, such as DAPI, was not tested). Using the software Adobe Photoshop version 7 , the outline of 3 sets of 4 adjacent bacteriocytes on a filament (starting with the bacteriocyte closest to the lateral ciliated cell) was traced. The 3 measurements were made in different areas of the gill. The outline ('total bacteriocyte outline', or TBO) included the microvillar space that is colonized by symbionts, and the bacteriocytes proper. Then, outlines of the area covered by symbionts in the same cells (the 'symbiont outline', or SO) were traced in a separate Photoshop layer. Finally, the areas within the TBO and SO were determined using $\mathrm{NIH}$ Image 1.63, and the percentage of symbiont occupation was calculated (SO area $\times$ TBO area $^{-1} \times 100$ ).

The number of dark granules (presumed products of lysed bacteria; Southward 1986, Le Pennec et al. 1988) was determined in 3 replicates of 4 consecutive bacteriocytes on the semi-thin sections, and averages per treatment were calculated.

Due to the limited number of samples available for these experiments (in part due to mortality, as mentioned in 'Results'), statistical power to compare, using ANOVAs, the effect of both treatments and time on symbiont abundance is low. For this reason, statistical analyses are restricted to $t$-tests comparing the effect of feeding or sulphide on the percent symbiont occupation (or granule number), with samples taken at different times during the experiment grouped together.

\section{RESULTS}

The gill sections showed that symbiont density varied between treatments, and the microcosm experiments led to different trends in symbiont depletion that could be related to the imposed conditions. 


\section{Feeding experiment}

TEM observation confirmed the presence of extracellular symbionts in freshly collected specimens (Fig. 1A) and at the end of the experiment (Fig. 1B), and showed evidence of endocytosis in both cases. Individuals maintained in aquaria produced large organelles and dark granules (Fig. 1B).

Pre-experimental samples were consistently replete with symbionts (Fig. 1C). Thyasirids in the fed and
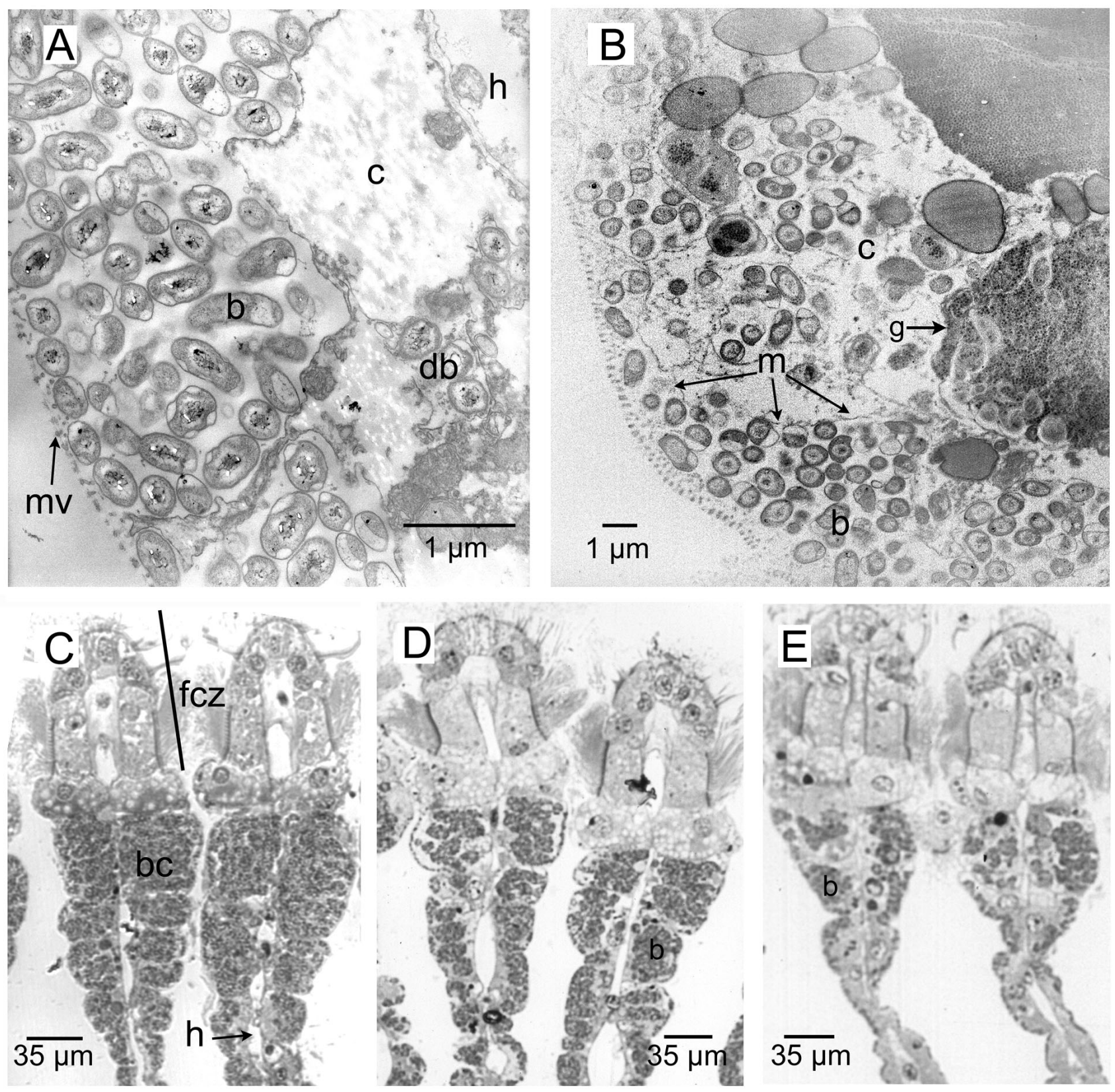

Fig. 1. Thyasira flexuosa. TEM and light micrographs of gill filaments, upon collection and at the end of feeding experiment. (A) TEM of a bacteriocyte in a freshly collected specimen. Bacteria (b) are located in pockets delimited apically by microvilli (mv) and basally by the bacteriocyte cell membrane; c: cytoplasm of bacteriocyte, db: degrading bacteria; h: hemocoel. (B) TEM of a bacteriocyte in a specimen kept $18 \mathrm{~d}$ without particulate food. Symbionts (b) can be seen extracellularly, as well as in various stages of lysis in dark granules $(\mathrm{g})$ within the bacteriocyte; c: cytoplasm of bacteriocyte; m: bacteriocyte cell membrane. (C) Light micrograph of the gill of a freshly collected specimen, with abundant symbionts. Darkly stained areas within bacteriocytes (bc) consist of bacterial symbionts; fcz: frontal ciliated zone; h: hemocoel. (D) Specimen exposed to particulate food, after 18 d; b: bacterial symbionts. (E) Unfed specimen after $18 \mathrm{~d}$; b: bacterial symbionts 
starved conditions showed a gradual decrease in relative symbiont abundance with time; after $18 \mathrm{~d}$, there were fewer symbionts left in thyasirids from both treatments (Fig. 1D,E). Symbiont decrease was more pronounced in the starved treatment (Fig. 2). The difference in percent symbiont coverage between specimens in the starved and the fed treatments (regardless of sampling time) was statistically significant ( $t$-test, $\mathrm{p}=0.006)$.

Dark granules were more numerous in the aquarium-maintained specimens (average per 4 bacteriocytes $\bar{X} \pm \mathrm{SE}=1.7 \pm 0.2$ ) than in the freshly collected ones $(\bar{X} \pm \mathrm{SE}=1.0 \pm 0.4)$; in addition, they were slightly more abundant in unfed thyasirids $(\bar{x} \pm \mathrm{SE}=1.9 \pm 0.3)$ than in fed individuals $(\bar{x} \pm \mathrm{SE}=1.5 \pm 0.2)$. The difference in granule number between individuals in the starved and fed treatments was nearly significant $(t$-test, $\mathrm{p}=0.09)$.

Very few symbionts in any observed specimen were seen to be dividing; no apparent difference in the quantity of dividing bacteria was noted between specimens maintained under different conditions.

Although thyasirid mortality could not be clearly determined for each container (the initial number of thyasirids per container was unknown, as some specimens were inadvertently collected along with the sediment cores), a high mortality ( $>50 \%$ ) caused a considerable reduction in specimen number in the 4 microcosms from Day 11 (from both fed and unfed treatments), and in 1 microcosm in the fed treatment from Day 18.

\section{Sulphide experiment}

Sulphide content in the experimental microcosms

Sediments that had settled for 4 wk had higher levels of interstitial sulphide than sediments that had just been sieved (a $t$-test revealed significant differences between treatments: $p<0.001$ ). Sediment from the 2 groups could be distinguished as having generally more, or consistently less, than $10 \mu \mathrm{M}$ dissolved sulphide. The quantity of dissolved sulphide did not always increase with depth in the aquaria; rather, there seemed to be patches with higher sulphide concentrations throughout the sediment column.

Thyasira flexuosa. TEM observation showed bacteria in freshly collected specimens (Fig. 3A), as well as in samples fixed during the experiment (Fig. 3B,C). After $3 \mathrm{wk}$, very few bacteria were visible among the microvilli; several bacteria in various stages of degradation were seen within the bacteriocytes (Fig. 3B).

The semi-thin sections showed symbiont density decreasing during the experiment, with very few remaining after 2 and $3 \mathrm{wk}$ (Fig. 3D-G). The percent

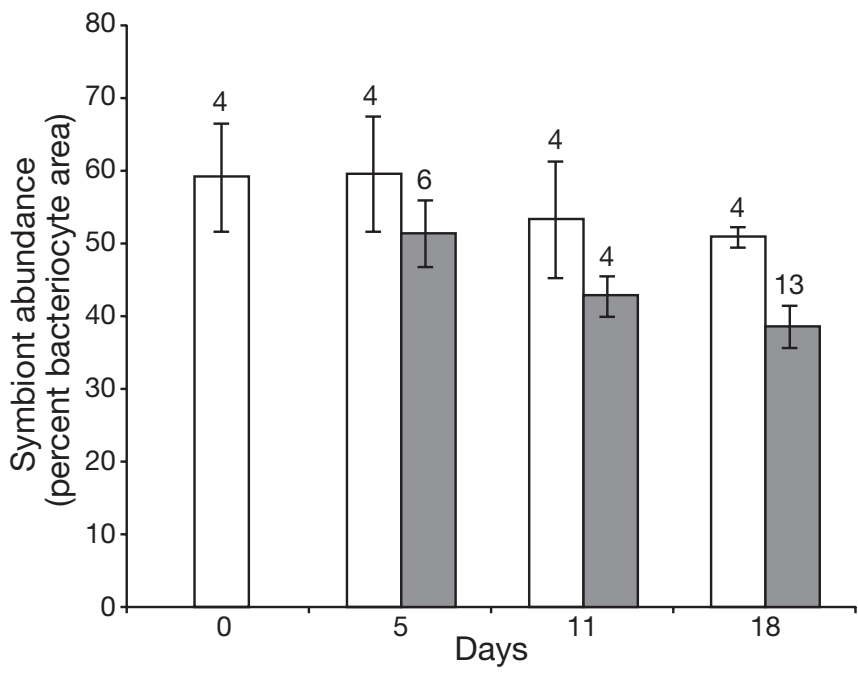

Fig. 2. Thyasira flexuosa. Decline in symbiont abundance in specimens maintained in starved treatment (grey bars) or fed treatment (white bars). Values are mean percent symbiont area within 4 bacteriocytes \pm SE. No. of specimens examined from each treatment is indicated above bars

symbiont coverage of bacteriocytes decreased at a faster rate in the low sulphide treatment (Fig. 4). The difference in percent symbiont coverage between individuals maintained in low and high sulphide treatments (with sampling time not considered) was nearly significant ( $t$-test, $\mathrm{p}=0.058$ ).

Dark granules were more abundant in Thyasira flexuosa maintained in low sulphide $(\bar{X} \pm \mathrm{SE}=0.9 \pm 0.1)$ than in high sulphide $(\bar{x} \pm \mathrm{SE}=0.4 \pm 0.2)$; the difference was significant ( $t$-test, $p=0.04)$.

Mortality rates in microcosms with high or low sulphide levels were low; losses were slightly higher in the low sulphide microcosms (total loss of 6 out of 47 specimens) than in the high sulphide microcosms (total loss of 1 out of 10 specimens).

Thyasira sarsi. Semi-thin sections of $T$. sarsi gills did not reveal obvious differences in symbiont abundance. However, some of the large pockets of symbionts visible in freshly collected specimens of T. sarsi (Fig. 5A) were less evident in specimens maintained for $3 \mathrm{wk}$ in aquaria (Fig. 5B,C). In the latter specimens, the bacteriocytes appeared reduced in area compared to the freshly collected samples, and had a more uniform intensity of staining. A comparison of samples maintained under different experimental conditions suggests that bacteriocytes occupied a smaller area in the specimens maintained in the low sulphide treatment (Fig. 5B), compared to those in the high sulphide treatment (Fig. 5C).

TEM observation showed more symbionts in the freshly collected samples (Fig. 5D) than in specimens maintained in aquaria (Fig. 5E,F). After $3 \mathrm{wk}$ in both 

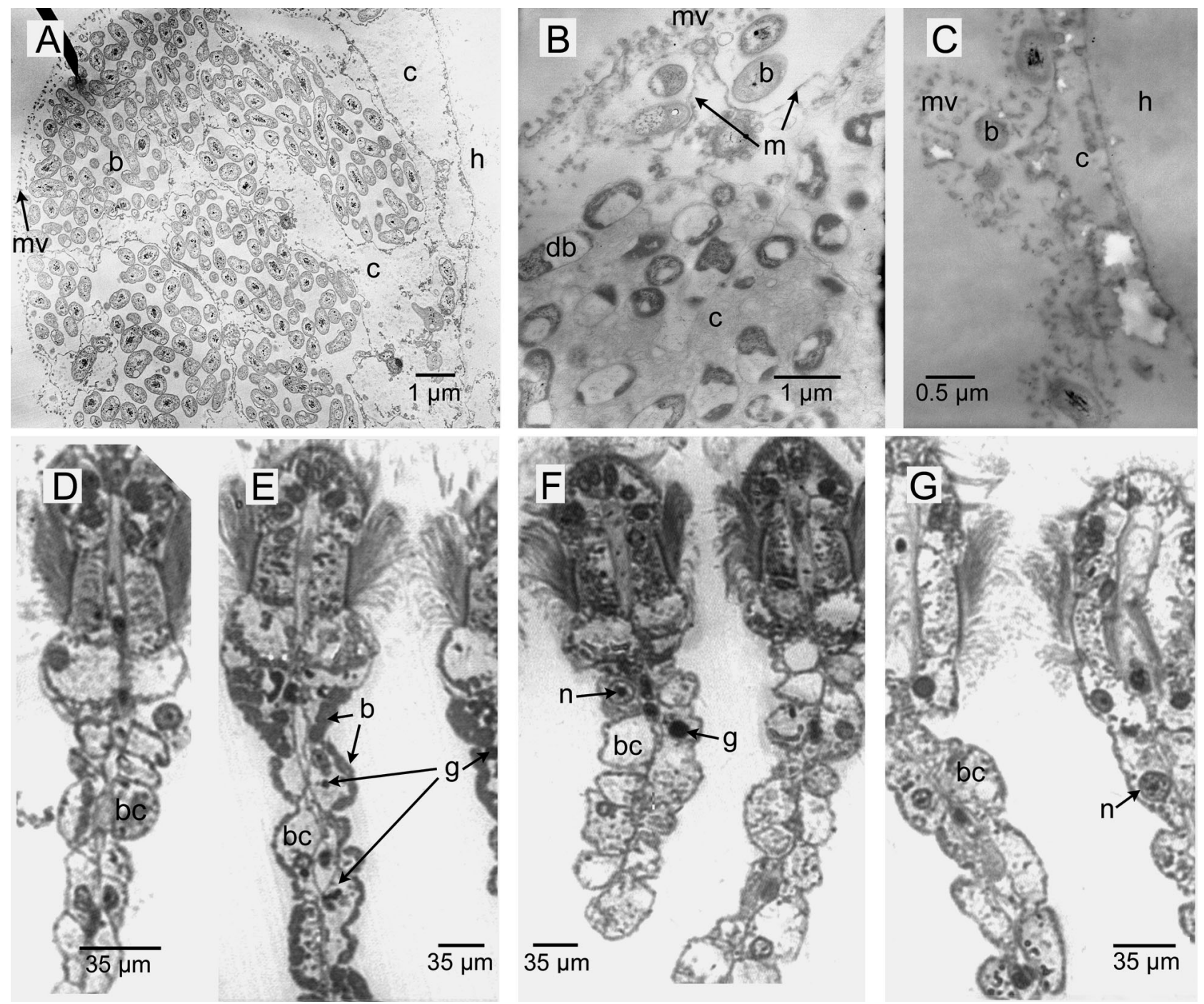

Fig. 3. Thyasira flexuosa. Light micrographs and TEM of gill filaments at different times during the sulphide experiment. (A) TEM of a bacteriocyte in a freshly collected specimen. Abundant bacteria (b) are visible, and are held in extracellular pockets delimited by microvilli (mv); c: cytoplasm of bacteriocyte; h: hemocoel. (B) TEM of a bacteriocyte in a specimen maintained for 3 wk in low sulphide conditions. A few symbionts (b) are still present extracellularly, but more are being degraded (db) within the bacteriocyte cytoplasm (c); m: bacteriocyte cell membrane; mv: microvilli. (C) TEM of a bacteriocyte in a specimen maintained for $3 \mathrm{wk}$ in high sulphide conditions. A few symbionts (b) are located extracellularly; c: bacteriocyte cytoplasm; h: hemocoel; mv: microvilli. (D) Light micrograph of a gill filament in a specimen maintained for $2 \mathrm{wk}$ in low sulphide. Very few symbionts are visible in the bacteriocytes (bc). (E) Gill filaments in a specimen maintained for $2 \mathrm{wk}$ in high sulphide; b: bacteria; bc: bacteriocyte; g: granules. (F) Gill filaments in a specimen maintained for $3 \mathrm{wk}$ in low sulphide; bc: bacteriocyte; g: granule; n: nucleus of bacteriocyte. (G) Gill filaments in a specimen maintained for 3 wk in high sulphide; bc: bacteriocyte; n: nucleus

low and high sulphide conditions, some symbionts remained in the microvillar spaces of bacteriocytes. Evidence of degraded bacteria within the cytoplasm of the bacteriocytes was seen in all specimens (Fig. 5D-F). Symbionts undergoing cell division were seen in both freshly collected and experimental samples kept in high sulphide conditions (Fig. 5D,F), but were not observed in specimens kept in low sulphide conditions. The morphology of several of the symbionts appeared altered in the specimens maintained in aquaria, especially those maintained in low sulphide conditions (Fig. 5E): their outline was irregular, and some regions appeared emaciated.

Parathyasira equalis. In semi-thin sections of Parathyasira equalis gill filaments from freshly collected specimens, the bacteriocytes were evenly stained throughout their surface (Fig. 6A). In contrast, staining in samples maintained in aquaria was more intense at the apical end of bacteriocytes (Fig. 6B,C). Samples maintained in high and low sulphide conditions could 
not be distinguished from one another based on staining intensity.

TEM observation showed symbiotic bacteria among the microvilli of all examined samples (Fig. 6D-F). The bacteria were more abundant in freshly collected samples (Fig. 6D) than at the end of the experiment, when there were very few symbionts left (Fig. 6E,F). Bacterial degradation products within bacteriocytes were mostly seen in samples that were maintained in the low sulphide treatment (Fig. 6E).

\section{DISCUSSION}

Symbiont abundance decreased with time in thyasirids maintained in experimental microcosms. Similar symbiont declines in aquarium-maintained bivalves have been reported previously (Dando et al. 1986, Hentschel et al. 2000) and may be related to a decrease in symbiont vigour while in unnatural maintenance conditions. However, the trends of symbiont decline with time in the different treatments are compelling and suggest that environmental factors influence symbiont abundance.

The greater decline of symbionts with time observed in the particle-starved and low dissolved sulfide treatments could be due to: (1) a decrease in symbiont vigour under unfavourable conditions, (2) nutritional stress in the host, (3) a combination of the two, as discussed below.

\section{Effect of particulate food}

The greater symbiont decline in particle-starved Thyasira flexuosa could be due to an increased rate of symbiont uptake and digestion in bacteriocytes, as a compensation for particulate food. The slightly higher number of granules in the starved individuals could support this interpretation.

An alternative explanation is that symbionts in particle-starved Thyasira flexuosa are dying faster, and/or dividing less frequently than symbionts in particle-fed individuals (dead symbionts could be engulfed and digested by bacteriocytes). This would imply that the well-being of the symbionts is somehow related to that of the host; this intriguing possibility merits further investigation.

\section{Effect of sulphide}

Comparisons of gills revealed a more pronounced decrease in symbiont occupation with time in Thyasira flexuosa specimens kept under low sulphide condi-

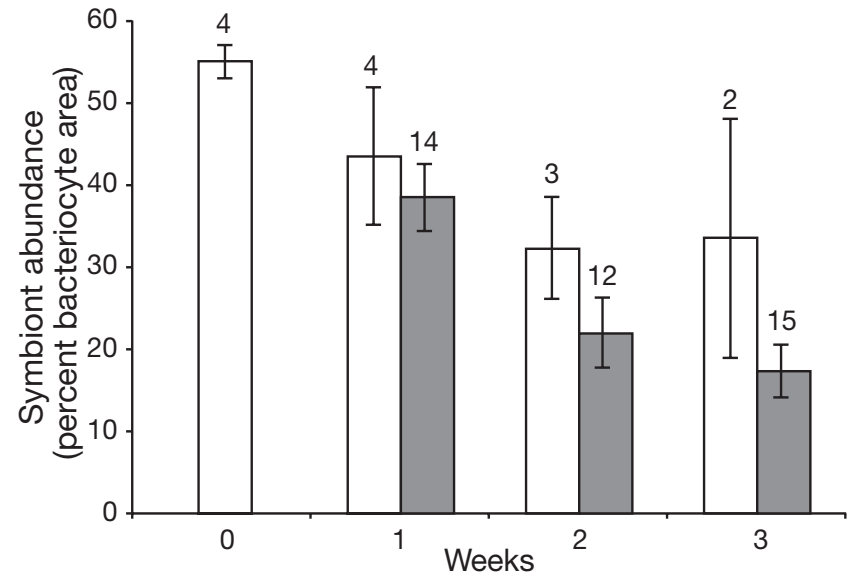

Fig. 4. Thyasira flexuosa. Decline in symbiont abundance in specimens maintained in sediments with low (grey bars) or high (white bars) sulphide content. Values are mean percent symbiont area within 4 bacteriocytes \pm SE. No. of specimens examined from each treatment is indicated above the bars

tions, compared to those maintained in high sulphide (Fig. 4). In Thyasira sarsi and Parathyasira equalis, bacteriocytes appeared smaller in specimens maintained in low sulphide, compared to those in high sulphide (Figs. 5B,C \& 6B,C) - similar differences in bacteriocyte size were used as markers for symbiont abundance in Bathymodiolus azoricus (Kádár et al. 2005).

Most likely, reduced symbiont vigour due to a lack of sulphide resulted in the lower abundances observed; a higher symbiont mortality rate might also have led to a greater number of bacteriocyte granules. Symbionts of Thyasira sarsi appeared more vigorous under high sulphide conditions ('normal' bacterial shape, dividing cells) than under low sulphide conditions (altered bacterial shape, no apparent dividing cells). Also, granules were more abundant in T. flexuosa (and possibly also in $P$. equalis) maintained under low sulphide conditions.

When comparing the abundance of symbionts remaining after 3 wk among the species studied, it appears that Thyasira flexuosa individuals lost a greater proportion of their symbionts than did T. sarsi or Parathyasira equalis. These differences may indicate species-specific differences in symbiont dependence (as suggested by reported differences in $\delta^{13} \mathrm{C}$ ratios; Dando \& Spiro 1993). Also, the symbionts within the different species of thyasirids could vary in their levels of tolerance to changes in sulphide.

The range of tolerance of host bivalves to changes in sediment chemistry may not be limited to the range of tolerance of their symbionts, especially when reduced sulphur levels are low, oxygen levels are sufficient, and the bivalves can gain enough food by particulate feeding. Specimens of Thyasira sarsi and Parathyasira equalis having $\delta^{13} \mathrm{C}$ ratios indistinguishable from het- 

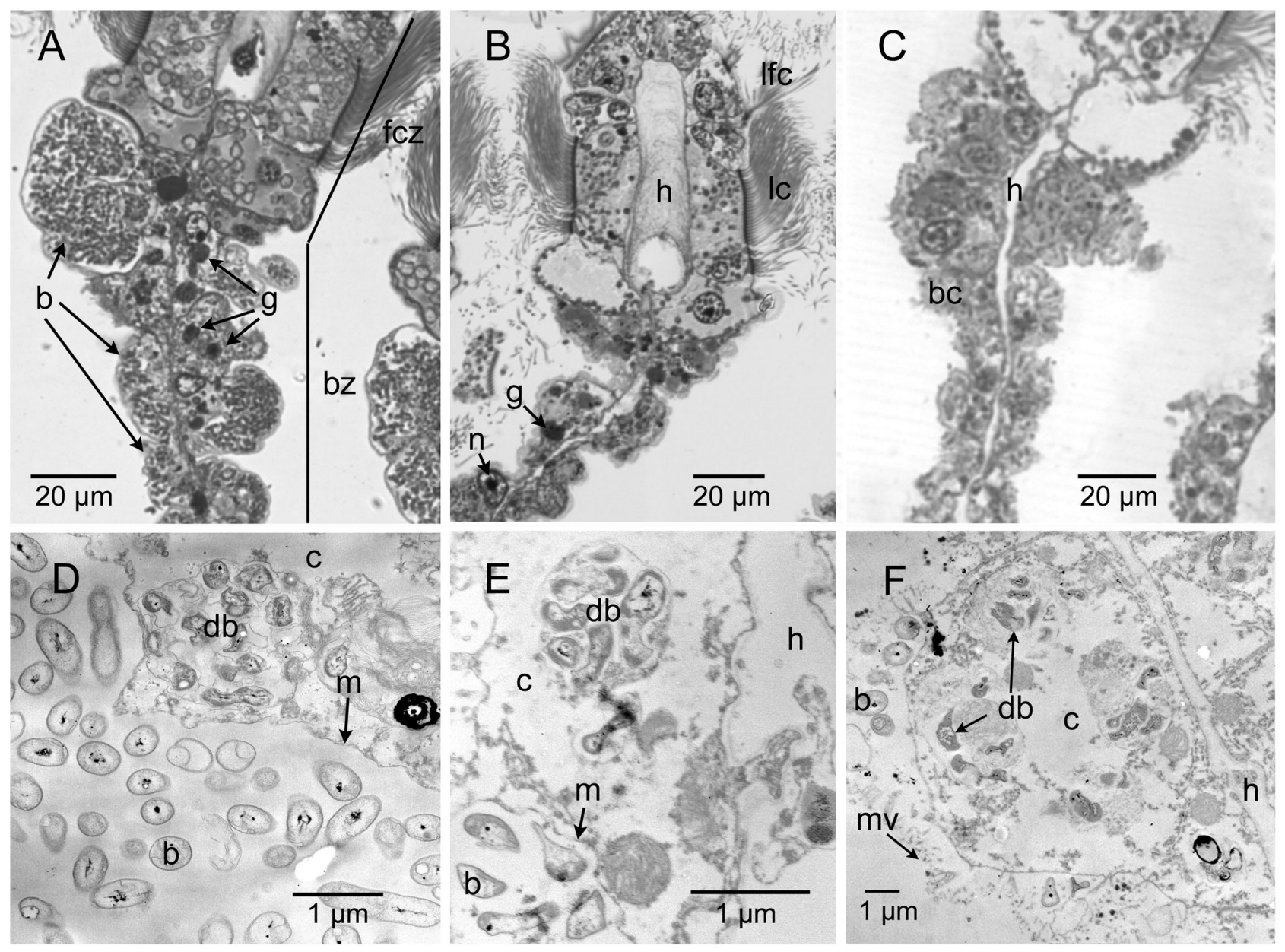

Fig. 5. Thyasira sarsi. Light micrographs and TEM of gill filaments. (A) Gill filament of a freshly collected specimen. Bacteria (b) are darkly stained inclusions in the apical zone of bacteriocytes; bz: bacteriocyte zone; fcz: frontal ciliated zone; g; granules. (B) Gill filament in a specimen maintained for $3 \mathrm{wk}$ in low sulphide; g: granule; h: hemocoel; lc: lateral cilia; lfc: latero-frontal cilia; $\mathrm{n}$ : nucleus. (C) Bacteriocytes in a specimen maintained for $3 \mathrm{wk}$ in high sulphide. bc: bacteriocyte; h: hemocoel. (D) TEM of the apical end of a bacteriocyte in a freshly collected specimen. Bacteria (b) are extracellular. Within the bacteriocyte cytoplasm (c), degrading bacteria $(\mathrm{db})$ are visible; m: bacteriocyte cell membrane. (E) TEM of a bacteriocyte in a specimen maintained for 3 wk in low sulphide, with a few bacteria (b) outside the cell, and some degraded bacteria (db) in the bacteriocyte cytoplasm (c); h: hemocoel; m: cell membrane. (F) TEM of a bacteriocyte in a specimen kept for 3 wk in high sulphide. Bacteria (b) are visible among the microvilli (mv); c: cytoplasm of bacteriocyte; $\mathrm{db}$ : degrading bacteria; $\mathrm{h}$ : hemocoel

erotrophic, non-chemosymbiotic bivalves were collected from the Gullmarfjord in Sweden at a season when available sulphide levels were very low (Dando \& Spiro 1993); the symbiont populations in these specimens were likely to be very reduced, or even absent, yet the bivalves were still alive. Similarly, the hydrothermal vent mussel Bathymodiolus azoricus can survive for over a month in aquaria without reduced sulphide (Kádár et al. 2005).

\section{Implications for natural populations}

The observed variability in symbiont abundance is relevant in the context of environmental change: it is known that the quantities of nutritive particles and of reduced sulphur can fluctuate spatially and temporally in chemosymbiotic bivalve habitats (Smith 1985, Gray et al. 2002). In fact, thyasirids are commonly found in environments subjected to significant changes, such as sediments recovering from severe eutrophication due to organic enrichment, or habitats that temporarily become anoxic (Pearson \& Rosenberg 1976). In such environments, they are often early colonists (LópezJamar et al. 1995) characterized by a large but unsustainable population size (up to 22000 ind. $\mathrm{m}^{-2}$, LópezJamar \& Parra 1997). While the population size of thyasirids may be controlled by sulphate reduction rates (Dando et al. 2004), that of their symbionts may also be controlled by particulate food availability. 

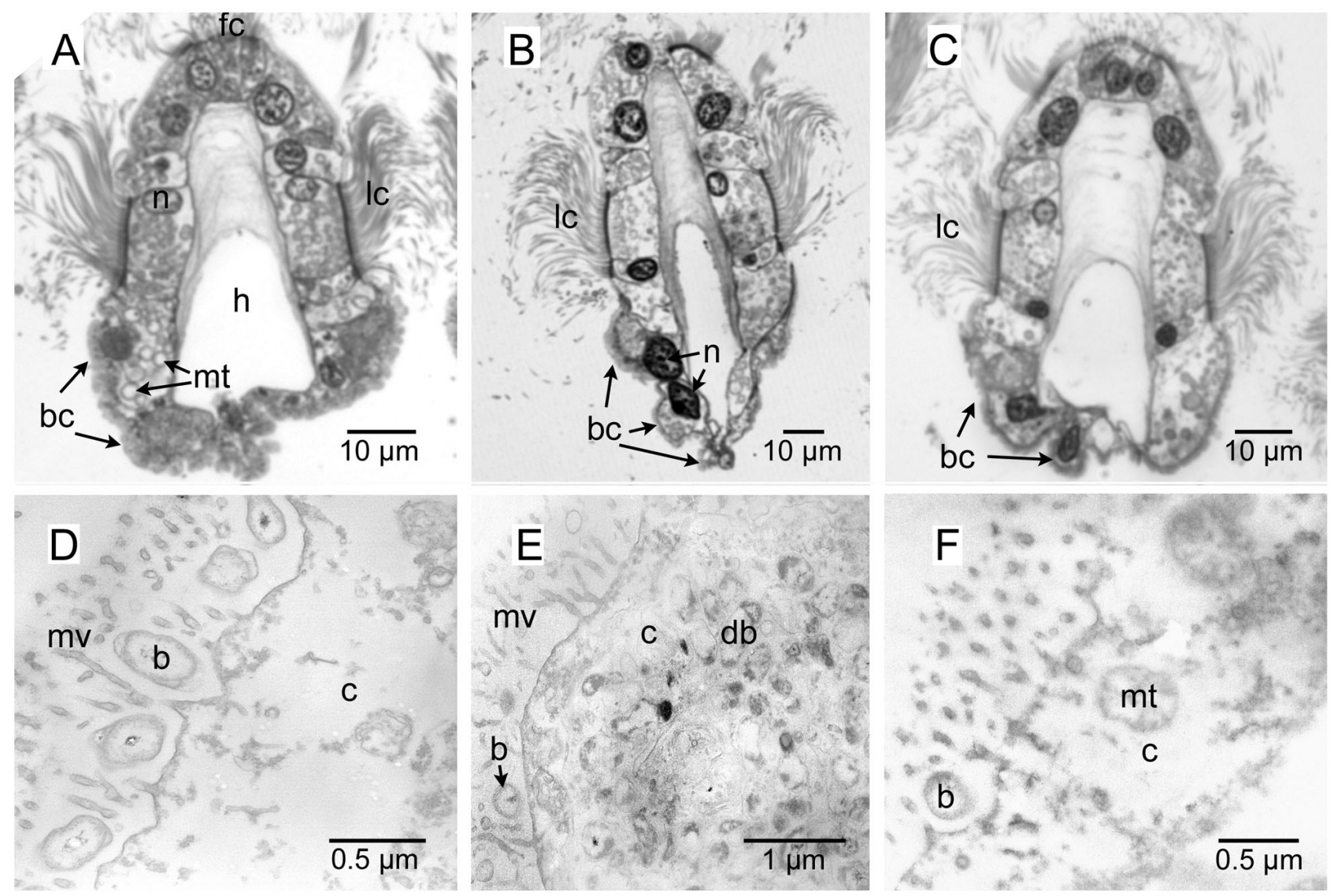

Fig. 6. Parathyasira equalis. Light micrographs and TEM of gill filaments. (A) Gill filament in a freshly collected individual. Bacteriocytes (bc) are located abfrontally and are densely stained; fc: frontal cilia; h: hemocoel; lc: lateral cilia; n: nucleus; mt: mitochondria. (B) Gill filament in a specimen kept for 3 wk in low sulphide; bc: bacteriocytes; lc: lateral cilia; n: nuclei. (C) Gill filament in a specimen kept for $3 \mathrm{wk}$ in high sulphide; bc: bacteriocytes; lc: lateral cilia. (D) TEM of a bacteriocyte in a freshly collected specimen. Bacteria (b) are located among microvilli (mv); c: bacteriocyte cytoplasm. (E) TEM of a bacteriocyte in a specimen kept for $3 \mathrm{wk}$ in low sulphide. Very few bacteria (b) are seen among microvilli (mv). Degrading bacteria (db) are seen within the bacteriocyte cytoplasm (c). (F) TEM of a bacteriocyte in a specimen kept for $3 \mathrm{wk}$ in high sulphide; b: bacterium; c: bacteriocyte cytoplasm; mt: mitochondrion

In these changing environments, observed yearly variations in $\delta^{13} \mathrm{C}$ ratios within populations (Dando \& Spiro 1993) may be reflective of changes in symbiont population size. It may be possible for thyasirids to reacquire symbionts, following unsuitable conditions, as described for Bathymodiolus azoricus (Kádár et al. 2005). The mode of transmission of thyasirid symbionts is unknown, but given their extracellular location and phylogenetic diversity (Imhoff et al. 2003), they are probably acquired from their environment, as are other symbionts of shallow-water chemosymbiotic bivalves (Le Pennec \& Beninger 2000).

The association between thyasirids and their symbionts appears highly flexible. Symbiotic thyasirid populations are able to persist in periods of low sulphide and become dominant again when reducing conditions return (Dando \& Spiro 1993). In contrast, most bivalves from hydrothermal vents cannot survive for long after the vents go extinct (Laubier \& Desbruyères 1984, Hessler et al. 1988); however, this may be due to low particulate food availability. It is not yet known whether thyasirids reported from hydrothermal vent sites (Southward et al. 2001) may outlive other symbiotic bivalves in their community, including mixotrophic Bathymodiolus species. It would be interesting to explore the longevity and population dynamics of symbiotic thyasirids in environments without reduced sulphur, to evaluate whether their symbiosis may be facultative.

Acknowledgements. We thank S. Parra, I. Frutos, E. LópezJamar and M. Albentosa Verdú from the Instituto Español de Oceanografía for their assistance in collecting thyasirids and running experiments in Spain. A. Aadnesen, P. Johannessen and T. Høisæter from the University of Bergen Biological Station, Espegrend helped to locate, collect and identify thyasirids in Norway. S. Barlow at the San Diego State Uni- 
versity Electron Microscopy Facility assisted with TEM imaging. Financial support was provided by the Scripps Institution of Oceanography Graduate Department, the American Malacological Society, the Baxter and Alma Ricard Foundation, and a National Science Foundation grant (OCE 99-07810, to HF). We thank the Biological Bulletin (Woods Hole) for permission to reprint Figs. 3A, 5B \& 6E from Dufour (2005).

\section{LITERATURE CITED}

Barry JP, Buck KR, Kochevar RK, Nelson DC, Fujiwara Y, Goffredi SK, Hashimoto J (2002) Methane-based symbiosis in a mussel, Bathymodiolus platifrons, from cold seeps in Sagami Bay, Japan. Invertebr Biol 121:47-54

Dando PR, Southward AJ (1986) Chemoautotrophy in bivalve molluscs of the genus Thyasira. J Mar Biol Assoc UK 66: 915-929

Dando PR, Spiro B (1993) Varying nutritional dependence of the thyasirid bivalves Thyasira sarsi and $T$. equalis on chemoautotrophic symbiotic bacteria, demonstrated by isotope ratios of tissue carbon and shell carbonate. Mar Ecol Prog Ser 92:151-158

Dando PR, Southward AJ, Southward EC (1986) Chemoautotrophic symbionts in the gills of the bivalve mollusc Lucinoma borealis and the sediment chemistry of its habitat. Proc R Soc Lond B 227:227-247

Dando PR, Ridgway SA, Spiro B (1994) Sulphide 'mining' by lucinid bivalve molluscs demonstrated by stable sulphur isotope measurements and experimental models. Mar Ecol Prog Ser 107:169-175

Dando PR, Southward AJ, Southward EC (2004) Rates of sediment sulphide oxidation by the bivalve mollusc Thyasira sarsi. Mar Ecol Prog Ser 280:181-187

Distel DL (1998) Evolution of chemoautotrophic endosymbioses in bivalves. BioScience 48:277-286

Donval A, Le Pennec M, Herry A, Diouris M, Moraga D (1988) Structures particulières du tractus digestif d'un bivalve symbiotique, Thyasira flexuosa Montagu (Thyasiridae). Haliotis 18:159-169

Dufour SC (2005) Gill anatomy and the evolution of symbiosis in the bivalve family Thyasiridae. Biol Bull (Woods Hole) 208:200-212

Duplessis MR, Dufour SC, Blankenship LE, Felbeck $H_{\text {, }}$ Yayanos AA (2004) Anatomical and experimental evidence for particulate feeding in Lucinoma aequizonata and Parvilucina tenuisculpta (Bivalvia: Lucinidae) from the Santa Barbara Basin. Mar Biol 145:551-561

Fullarton JG, Dando PR, Sargent JR, Southward AJ, Southward EC (1995) Fatty acids of hydrothermal vent Ridgea piscesae and inshore bivalves containing symbiotic bacteria. J Mar Biol Assoc UK 75:455-468

Gilboa-Garber N (1971) Direct spectrophotometric determination of inorganic sulfide in biological materials and in other complex mixtures. Anal Biochem 43:129-133

Gray JS, Wu RS, Or YY (2002) Effects of hypoxia and organic enrichment on the coastal marine environment. Mar Ecol Prog Ser 238:249-279

Hentschel U, Millikan DS, Arndt C, Cary SC, Felbeck H (2000) Phenotypic variations in the gills of the symbiontcontaining bivalve Lucinoma aequizonata. Mar Biol 136: 633-643

Herry A, Diouris M, Le Pennec M (1989) Chemoautotrophic symbionts and translocation of fixed carbon from bacteria to host tissues in the littoral bivalve Loripes lucinalis (Lucinidae). Mar Biol 101:305-312
Hessler RR, Smithey WM, Boudrias MA, Keller CH, Lutz RA, Childress JJ (1988) Temporal change in megafauna at the Rose Garden hydrothermal vent (Galapagos Rift; eastern tropical Pacific). Deep-Sea Res 35:1681-1709

Imhoff JF, Sahling H, Süling J, Kath T (2003) 16S rDNA-based phylogeny of sulphur-oxidising bacterial endosymbionts in marine bivalves from cold-seep habitats. Mar Ecol Prog Ser 249:39-51

Kádár E, Bettencourt R, Costa V, Santos RS, Lobo-da-Cunha A, Dando P (2005) Experimentally induced endosymbiont loss and re-acquirement in the hydrothermal vent bivalve Bathymodiolus azoricus. J Exp Mar Biol Ecol 318:99-110

Laubier L, Desbruyères D (1984) Les oasis du fond des océans. Recherche 15:1506-1517

Le Pennec M, Beninger PG (2000) Reproductive characteristics and strategies of reducing-system bivalves. Comp Biochem Physiol A 126:1-16

Le Pennec M, Diouris M, Herry A (1988) Endocytosis and lysis of bacteria in gill epithelium of Bathymodiolus thermophilus, Thyasira flexuosa and Lucinella divaricata (Bivalve, Molluscs). J Shellfish Res 7:483-489

Le Pennec M, Donval A, Herry A (1990) Nutritional strategies of the hydrothermal ecosystem bivalves. Prog Oceanogr 24: $71-80$

Le Pennec M, Beninger PG, Herry A (1995a) Feeding and digestive adaptations of bivalve mollusks to sulphide-rich habitats. Comp Biochem Physiol A 111:183-189

Le Pennec M, Herry A, Johnson M, Beninger P (1995b) Nutrition-gametogenesis relationship in the endosymbiont host bivalve Loripes lucinalis (Lucinidae) from reducing coastal habitats. In: Eleftheriou A, Ansell AD, Smith DJ (eds) Biology and ecology of shallow coastal waters. Olsen \& Olsen, Fredensborg, p 139-142

López-Jamar E, Mejuto J (1985) Bentos infaunal en la zona submareal de la ría de La Coruña. I. Estructura y distribución espacial de las comunidades. Boll Inst Esp Oceanogr 2: 99-109

López-Jamar E, Parra S (1997) Distribución y ecología de Thyasira flexuosa (Montagu, 1803) (Bivalvia, Lucinacea) en las rías de Galicia. Publ Espec Inst Esp Oceanogr 23: 187-197

López-Jamar E, Francesch O, Dorrío AV, Parra S (1995) Longterm variation of the infaunal benthos of La Coruña Bay (NW Spain): results from a 12-year study (1982-1993). Sci Mar 59(Suppl 1):49-61

Pearson TH, Rosenberg R (1976) A comparative study of the effects on the marine environment of wastes from cellulose industries in Scotland and Sweden. Ambio 5:77-79

Péquignat E (1973) A kinetic and autoradiographic study of the direct assimilation of amino acids and glucose by organs of the mussel Mytilus edulis. Mar Biol 19:227-244

Pile AJ, Young CM (1999) Plankton availability and retention efficiencies of cold-seep symbiotic mussels. Limnol Oceanogr 44:1833-1839

Smith KL Jr (1985) Deep-sea hydrothermal vent mussels: nutritional state and distribution at the Galapagos Rift. Ecology 66:1067-1080

Southward EC (1986) Gill symbionts in thyasirids and other bivalve molluscs. J Mar Biol Assoc UK 66:889-914

Southward EC, Gebruk A, Kennedy H, Southward AJ, Chevaldonné P (2001) Different energy sources for three symbiont-dependent bivalve molluscs at the Logatchev hydrothermal site (Mid-Atlantic Ridge). J Mar Biol Assoc UK 81:655-661

Wright SH (1982) A nutritional role for amino acid transport in filter-feeding marine invertebrates. Am Zool 22:621-634 